\title{
Research on Judicial Reform of Chinese Jury System
}

\author{
Qi $A n^{1}$ \\ ${ }^{1}$ Sichuan University Law School, Cheng Du, Sichuan, China, 610207
}

Keywords: Jury System, Functional Value, Reform and Improvement

\begin{abstract}
Jury system is the judicial activity of the participation of citizens in the forms of democracy, it is an important way to safeguard the basic rights of citizens. This kind of system plays an essential role in the process of rule of law all over the world. The jury system in China has undergone continuous development. However, current jury system-the people's jury system has its own shortcomings, these shortcomings limit the function of the system. The jury system's future has always been the theoretical and practical focus of Chinese Procedure Law. The article focused on reform and improvement of jury system in China and the development of system of people's jurors, analyzed the people's jury system, summarized the problem of existence and inadequacy from the Value expected and legal regulations in two layer, put forward the conception about reforming and perfecting the people's jury system, to make this crucial legal system of the function definition more scientific and reasonable, more inline with China's judicial practice and the development of the rule of law orientation.
\end{abstract}

\section{Introduction}

In common law system, jury system refers to a non-professional judges or umpires career as jurors or jurors to attend court, and judges jointly exercise judicial system. However, this legal system is not an unique one, it can also be seen in civil law countries, which is called the trial system. According to "Brian Stone's Law Dictionary" explanation, jury system refers to a jury proceeding through a certain pick out, was given to the fact that the issues involved in the case have made identification and referees power groups. The famous researcher Tocqueville defined jury as: that at any time invited a few citizens to form a jury, temporarily giving them the power to participate in the trial. In the concept of "American law dictionary", jury is the fact that for a number of legal proceedings issue, it is a ruling by a number of groups of citizens. Based on those definition, we can see the common features of he jury system is by selecting a number of citizens randomly, let them form a temporary group that involved in the case, those citizens, also known as the "juror", have the power of finding out the truth of the case. In civil law countries, trial system allows professional and non-professional people make sentence together, jointly decide regime factual and legal issues of the case. People refer to the ordinary citizen jury system was chosen as people's assessors, participation in national administration of justice activities, together with the exercise of the powers of the judge justice system. Both common law and civil law emphasize the participation of citizens during the court, make it possible for citizens to get involved in the judicial process, also, can be seen as constraints to judges. In China, the definition of "people's jury system" is that in adjudicating cases of first instance, the case of the ordinary procedure can invite people to the identity of the people to participate in the full court for trial juror. It can be seen clearly that while in civil law countries the trial system is similar to be called "jury", China's people's jury system ,the evolution of the former Soviet Union, is completely different from the definition of jury system in neither common law system nor civil law system .

\section{The Purpose and Function of the Jury System}

At present, China is in the process of social transition, various contradictions have been raised up frequently, the quantity of cases increased year by year ranging from a variety types of litigation, especially in some conflicts, there is significant impact cases occurred. However, due to wide spread of network, involvement of the media, the masses of onlookers can easily get access to the 
information, resulting in many cases deviated from the rule of law in the handling track. In recent years, a number of noticeable case, such as the Xu Ting case, Wu Ying case, Nie Shubin case and so on, have drawn public attention with the exposure of mess media, this phenomenon fully demonstrates the strong public demand for judicial information and surveillance and the exercise of the right of expression. Since people hold a negative attitude towards the credibility of judicial, the legislators are now focus on the method of improve the quality of verdict, try to "make each person feel the jusice". As a result, expand the public sector, rise up the pace in terms of the development of democracy and justice, enhance the judicial credibility, have become an inevitable requirement of the development direction of China's judicial reform.

Public participation in the jury system can be seen as a way of justice, to absorb into the referee an important public institution, in order to restrict public rational judicial rationality, for the rule of law in countries. As an important consent of China's legal system and continuously push forward the socialist construction process of the rule of law, the reform of jury system in China emphasis more and more on the function of the jury system, thus the need to improve the current situation of jury system has become more and more urgent. However, since this legal system is not an express provision in China's Constitution, the application of specific procedures is lack of uniform. Although the jury system has been widely used, its functional role is not been clearfield yet, especially the current application of jury system of China is quite unbalance, those remote areas where lack of financial support, the economy and human cost of jury can be a burden. That make jury system today more likely to be an dispensable court procedure, far away from the original legislative purpose. Therefore, an urgent need for the functional value of this system was to be planned, in order to make jury system in line with the requirements of the re-configuration of its function. As a practitioner and witness of China's judicial reform, the author of the jury system will discuss the effect of the operation of jury system in judicial practice, then trace the history of the development of China's jury system, summary experience from advanced foreign practice, finally compared the proposed law in line with the vision of the ideal of the jury system construction scheme.

\section{The Purpose of the Jury System}

"Purpose" as a basic category of philosophy, is an ideal target people in a conscious activity as needed, based on the objective nature of things and the understanding of the law and formation. Objective jury system refers to the design and use of jury system objectives to be achieved. In common law countries, the purpose of the establishment of the jury system is the use of ordinary common sense and experience to ensure the reliability of the judicial judgment. In cases that involve fundamental human rights like murder, manslaughter etc., the participation of jury can be seen as an efficient way of judicial restraint, which is the core of its "due process" and "procedural guarantees". In civil law countries, specialized legal knowledge aggravated public sectors and professional class isolation on the legal understanding of the purpose of the jury system is to make public opinion into the judicial order to avoid arbitrary legal person, law and society closer avoid legal from the community. The most significant difference between the two legal systems of the jury system is the purpose of jury system, jury system present restraints on the power of the president while trial system not .

In China, the judicial system has to cope with the rapid change of social environment, the purpose of jury system is also constantly changing. For a long time, because of the misunderstanding of judicial democracy (known as a "great democracy" ), resulting in a democratic judicial equivalent to public justice, and lead to the misconceptions of the judiciary independence and judicial professionalism and judicial democracy. (2) This type of misunderstanding also affects the function of the jury system, particularly its institutional setting goals. Ningxia Border Region and in the early days, the main mechanism of social control is a political ideology. Jury was seen as a political system which grafted onto the justice system, but did not integrate into the justice system. In that particular historical period, the implementation of the jury system is not so much to use the law to determine the judicial activity, but as a political activities with the political stance and 
ideology to judge, not only for justice to be accepted as part of the "people's democratic dictatorship", but also as a symbol of judicial democracy, of course, to win legitimacy.

\section{Function of Jury System}

The basic function of jury system is to restrict the power of justice. The involvement of jurors in the trial, make it possible to let citizen distinguish right from wrong based on quasi common sense and moral conscience, which judges might not see, make a more accurate administration of justice. Thus the judge will be able to effectively compensate for the lack of willingness to communicate with the public defect, effective control of the judge's jurisdiction enhance rational of judicial referee, minimize the possible of injustice verdict, enhance the fairness of justice, at this level, the jury can be seen as a citizen "freedom patron saint."

Secondly, the jury system can safeguard democracy and justice. Tocqueville said: "The jury is only as a judicial body, but look fairly narrow view of things overflow, because although it is a huge impact on the outcome of the proceedings, but it itself is a large social destiny much impact. Thus the jury first and foremost a political system, and it should always be to evaluate it from this point of view. "

Besides, the jury system can promote judicial integrity. With the supervise from the citizens, it has the power to pervent corruption during the court. Jurors involved in the trial judge restricting the abuse of power and effective measures. On one hand, the jury and the trial judge can make the common judicial activities to enhance public participation degree, unveil the mysterious face of judicial, prevent so-called "black-box operation" effectively. On the other hand, the jurors involved in the trial judge can effectively reduce the chance of unjust sentence. The lack of the participation from a third party make it possible for a judge to misconduct, but if a judge met with a number of its jury trial together, even sitting in front of temptation the judge will bound to think twice, provide a way of carefully exercise judicial jurisdiction. By absorbing people involved in the trial process, jury system find a effective way of civilian oversight to a large extent, supervise the abuses of power, capricious and arbitrary behavior, etc., to promote judicial integrity, safeguard justice.

Another goal of jury system is enhance judicial authority. According to Tocqueville, the jury can be used as one of the most effective means of educating people. The jury system can be seen as the concept of civic rights, for citizens themselves, they will form law-abiding habit through the jury's words and deeds, it can increase the legal awareness of citizens by no means. The specific identity of the jury's decision carries more expectations of people, as a member of the public, the jury's duty can be seen as an objective judgment from a non-legal background to understand the law involved in the trial process, the legal principle of injecting themselves understood in the language in a particular way to the side of people quoted, publicity to "social person "identity outside exchanges, can form a good shot jurisdiction effect, reduce public suspicion, resentment and misunderstanding of the judiciary, enhance trust, understanding and support for the judiciary, improve the legal belief of the whole society.

\section{The Status of Chinese Jury System}

Research on Jury System in Mainland China remained weak, the influence of academic articles about the jury system is limited. Over the past decade, the leadership of the jury system including the Supreme Court has repeatedly stressed the importance, August 28, 2004 the NPC Standing Committee formulated the "Decision on improving the people's jury system," the single law, is the milestone of the jury system, the implementation of the legislative and judicial basis. But studies theorists jury system still stalled in the macro research and the introduction of foreign jury system, build the perfect jury system still has a long way to go.

Formal attention and the practical effect of dislocation are important. Since the eighties, the leadership of the legislature and the judiciary has always attached great importance to the jury system, the former chairman of the National People's Congress Li Peng, former Supreme Court President Xiao Yang and Wang Shengjun incumbent on both the importance of the jury system made an important elaborated as Wang Shengjun work conference in the National People's Court jury pointed out, "to strive to make the jury system in resolving social conflicts in the new act, there 
is a new development in the promotion of social harmony, there are new achievements in establishing the authority of the judiciary."

Throughout the development process of the jury system, although several ups and downs, but never form a clear role orientation, the ultimate function of jury system should play the role of "supernumerary judge" or "expert advisor", or only represent general public opinion, in practice and academia has been still under lively debate. In the context of judicial reform in China, the function of jury system remains a profound subject, how to redefine this legal system and reconstruct this procedure have become an important issue.

Based on China's current legislation, the scope of the case in which the jury can participate in the provisions are summarized as "greater impact" of first instance cases, or cases filed by the parties, the lack of detailed rules and regulation make the application of this system quite different from one and another. Although the selection of jury is determined randomly, in practice, this random selection pattern regardless of inconvenience that might occur, make it even more difficult to implement this system. With the generally determination by the court, the selection of jurors assessors might cause quite a long time.

\section{Reconstruction of Chinese Jury System}

Establish constitutional status. Though jury system can be seen as an important part of the judicial system, the constitution does not clearly defined yet, stable foundation is difficult to obtain space for the development and implementation; at the same time, by participating in jury Judicial Power sharing, every citizen should enjoy the fundamental political rights is an important aspect of basic civil rights, it should be established in the fundamental law of a state constitution. China's Constitution Law (1982) was based on judicial background that emphasizes litigation efficiency, weight efficiency more than justice. However, the current judicial reform indicate the change attitude of the legislator, the authorities are putting more and more attention on the effect of justice and judicial credibility, provide a perfect background for the reconstruction of jury system on the level of Constitution Law.

Clear the jury system applicable scope of the case. Investigation of the American jury system can be found in the trial of criminal cases in the United States, as long as the defendant could be sentenced to six months imprisonment, the accused will have the right to trial by jury. Also, as long as the monetary compensation, the parties have the right to ask for a jury trial. Thus, based on foreign legislative experience and China's judicial practice, jury system can be applied intended for situations that involve groups of interest, the local people concerned about high numbers involved, the parties likely to intensify conflicts involving minors protection and other larger social impact of the case and so on.

Broaden the range of elective jurors. Jurors will meet the conditions and requirements for qualification and reflected widespread public participation in the democratic principle of combining, the selection rule of jurors should be clarity..Implement the original intention of the jury system is to enable people to share the judicial power, judicial reflect democracy and strengthen legal education of citizens in the whole social credit mechanism of the formation of health, to create a favorable legal environment. Therefore, it should be possible to broaden the scope of jurors elected, so that as many as citizens are able to participate in the judicial process.

Improve the elective mechanism juror. First of all, we should establish a pool of candidates for jurors. Any citizen of the area the right to vote, except in special legal body should serve as jurors, should be included in the jury pool. Make sure every citizen can understand the obligation of jury. Secondly, the implementation of pre-trial should be randomly selected. Currently, the most common selection rule in the court is the judge arbitrarily determined assessor personnel, the formation of a large number of jurors appointed, often involved in the actual jury of staff has focused on the situation in the minority staff, went against the meaning of democracy and universal representation of people's assessors. Thus, the provisions can not be given by the only side, both parties have the right of question the jury candidate. As for a juror, he or she cannot avoid the responsibility of jury without a proper reason such as health condition, Finally, to carry out a case 
of a choice, one vote system should be used of jurors after the trial, in a certain range and the number of jurors in the trial were randomly selected, a case of a choice, thus enhance legal literacy of the whole society.

The implementation of a limited jury system. Based on judicial function in China, in terms of cases involve the protection of human rights, crime and punishment, and criminal cases involving freedom of the accused and those cases have significant impact on society, should a better mprovment of the public participation. Therefore, the jury system in criminal cases can be implemented, taking into account the large number of criminal cases, it is impossible to apply jury system in each criminal case, thus considering the current situation in China, jury system can be implemented with limited scope, the defendant may be sentenced to imprisonment for more than a decade , major criminal cases to life imprisonment or the death penalty for a jury trial. Because the defendant was facing a possible sentence of long freedom punishment or the death penalty, let a non-relation group get involved in the case provide a more efficient way to protect the defendant's basic human rights.

In China, distrust of the jury from both judge and citizens is a serious problem, judges considered the people's jury trial is not liable to the result of the case, the final verdict still lay in judges' hand, so even if the people's assessors opinion are correct, it can be only seen as a reference, when only likely to be adopted in agreement with their opinions. That can lead to the negative consequence that the enthusiasm of people's jurors commented will be getting lower and lower, the judge's role in increasing people's jurors contempt, eventually causing people assessors complete formality. To avoid this situation and make the reform of the jury system perfect, the key is to establish a sense of democracy and set up certain restrictive rules for judges. Only democracy can enhance judicial awareness of judges to a certain height, in order to fully mobilize the enthusiasm of the use of the jury system, thus the jury system can be implemented effectively.

\section{Conclusion}

From scratch to be detailed, from simple to complete, from scattered to the provisions of special legislation, people's jury system in China, through arduous development process, ushered in a rare development opportunity. Based on Chinese status and conditions, we need to define the correct function of the jury system, find timely manner to improve the legislative problems and shortcomings in the administration of justice, the rule of law fully absorb those beneficial parts of foreign countries' jury system. Explore and innovate under the circumstances of China legal system, we will certainly be able to build a suitable jury system for China's local legal culture and judicial tradition complying with judicial reform.

\section{Reference}

[1] Bentham J . The Art of Packing Juries, Works edn, vol . V, Bowring, London, 1843, quoted in Marshall, op. cit .

[2] Brian J. Ostrom, Neal B. Kauder, Examining the Work of State Courts: A National Perspective from the Court Statistics Project, New York: National Center for State Courts, 1996, p. 30.

[3] L. W. Levy, The Palladium of Justice: Origins of Trial by Jury, Chicago: Ivan R. Dee, 1999, p. 25.

[4] Terence Ingman, The English Legal Process, New York: Blackstone Press, 1994, p. 445.

[5] R. Cornish. The Jury, Allen Lane: The Penguin Press, 1968, p. 10. 